\title{
Optimization Research on Middle School Students' Methods of Solving Word Problems with Equations: Taking the Mistake in "Taking a Taxi" for an Example
}

\author{
En-qing Dai ${ }^{1, *}$
}

\author{
${ }^{1}$ Yichang No. 9 Middle School, Hubei 443000, China \\ *Corresponding author.Email: dai_enqing@126.com
}

\begin{abstract}
Solving word problems with equations or equation sets is regarded as the important teaching content by educators in mathematics in China, but there is still a phenomenon of one-sided thinking in solving problems, the mistake such as "taking a taxi" is a typical example. Aiming at solving the current methods with limitations, this paper puts forward "the method of finding the whole" and "the method of finding the whole in a broad sense" based on the logic principle of sufficient and necessary condition and the essential definition of equation. By finding out all the equality relationships and inequality relationships in the proposition, one can correctly solve the word problems represented by "taking a taxi" and establish relatively rigorous and practical solutions.
\end{abstract}

Keywords: all the equality relationships, sufficient condition, necessary condition, the method of finding the

whole, the method of finding the whole in a broad sense

\section{INTRODUCTION}

At the beginning of the last century, Bailey, a British mathematics educator, and other British mathematics educators launched the modernization movement of mathematics education and proposed that the purpose of mathematics teaching should emphasize application [1]. And solving word problems with equations or equation sets is a content that can reflect the application characteristic of mathematics.

Solving word problems with equations or equation sets is also regarded as an important topic and teaching difficulty by educators in mathematics in China [2]. The existing problem-solving methods lack an important foundation that is, finding out all the equality relationships and inequality relationships, thus resulting in mistakes in problem-solving for many years. Due to the controversy over the method of the conclusion of this topic, not only the difficulty in teaching has not been addressed, but also the frequent occurrence of the mistake in "taking a taxi" for a long time is hard to avoid. Based on the definition of equation [3], the author puts forward "the method of finding the whole". And according to the theory that a system of linear equations has a unique solution [4], "the method of finding the whole" is proved to be effective, which can not only find a solution to the topic of solving word problems with equations or equation sets, but also overcome the difficulty. On this basis, "the method of finding the whole in a broad sense" can ensure that the problem of "taking a taxi" is correctly solved.

\section{METHOD OVERVIEW AND CONTROVERSIAL EXAMPLES OF SOLVING WORD PROBLEMS WITH EQUATIONS OR EQUATION SETS}

\subsection{Method overview}

According to the analysis of the method used by the People's Education Press of China (hereinafter referred to as PEP) to solve word problems with equations or equation sets, the existing problem-solving methods are divided into four basic steps: determining the basic quantity, analyzing the relationship between quantities, looking for the equality relationships, and establishing an equation [5-6]. In this process, there are three problem-solving methods. One is the most widely used literal translation method, that is, in solving the problem, by considering the key sentences in the problem setting and finding out the relationships among quantities, directly "translating" the mathematical language into algebraic relations to list the equations; The second is the backward inference method, that is, conducting rigorous reasoning and analysis from the back to the front through backward inference to list the equations; The third is the table method, that is, analyzing the known quantities and unknown quantities in the problem in the form of table to find out the equivalent relationship among quantities ${ }^{[7]}$. However, the literal translation method focuses on finding out the equivalent relationship under sufficient conditions, while the 
backward inference method focuses on finding out the equivalent relationship under necessary conditions, and the table method is cumbersome to use. Therefore, the method of solving word problems with equations is one-sided. Besides, it is not conducive to finding the hidden conditions in problems, and to guiding students to establish an efficient classification method, thus leading to wrong solutions and missing solutions [8-10].

This paper takes the mistake in "taking a taxi" for Example and summarizes the errors and problem-solving paradigm in textbooks and supplementary books as follows.

\subsection{The mistake in "taking a taxi" that should cause concern}

The problem of "taking a taxi" first appeared on page 85 of the second volume of mathematics textbook for grade one of junior middle school published by PEP in January 2001. As a problem in the compulsory education textbook, it means that it is a problem for all first-year junior high school students in China, that is, all twelve or thirteen-year-old children in China.

Problem 1: The flag-down fare in a city is 10 yuan, which means one needs to pay 10 yuan for a driving distance within $5 \mathrm{~km}$. After reaching or exceeding $5 \mathrm{~km}, 1.2$ yuan will be added for each additional kilometer (the part less than $1 \mathrm{~km}$ is counted as $1 \mathrm{~km}$ ). Now someone takes this kind of taxi from place A to place B and pays 17.2 yuan. What is the approximate distance from place A to place B? In addition, students are required to solve the problem with inequalities.

In the teacher's teaching book, PEP provided a wrong solution: suppose the distance from place A to place B is $\mathrm{x}$ $\mathrm{km}$, and according to the meaning of the problem, $16 \leq$ ( $\mathrm{x}$ -5) $1.2+10<17.2$ can be listed.

In the above solution, $(\mathrm{x}-5) 1.2+10$ means the paid fare, $16 \leq(\mathrm{X}-5) 1.2+10<17.2$ means: the paid fare can be 16 yuan, or any value within the range of $16-17.2$, which is inconsistent with the meaning of the words "pays 17.2 yuan" in the problem, so it is wrong.

In November 2001, in the newly published textbook, PEP deleted the problem and solution of "taking a taxi", instead of correcting the mistake.

As PEP is an authoritative and influential publishing house for primary and secondary school textbooks in China, since then, many supplementary textbooks have followed its method of solving the problem of "taking a taxi", making this mistake occur frequently for at least 16 years, and the mistake has not been corrected.

Table 1. The mistake in "taking a taxi" made and concealed by textbooks and supplementary books

\begin{tabular}{|c|c|c|c|c|c|c|}
\hline Number & $\begin{array}{c}\text { Date of } \\
\text { publication }\end{array}$ & $\begin{array}{l}\text { Printing } \\
\text { Edition }\end{array}$ & Title & Publishing House & Page Number & Wrong Equation \\
\hline 1 & 200101 & $\begin{array}{c}\text { Edition } 1 \\
\text { Impression } 1 \\
\end{array}$ & $\begin{array}{c}\text { a compulsory } \\
\text { education textbook }\end{array}$ & PEP & $\begin{array}{c}\text { Teacher's } \\
\text { bookP187 }\end{array}$ & $\begin{array}{c}16 \leq(x-5) 1.2+10< \\
17.2\end{array}$ \\
\hline 2 & 200111 & & $\begin{array}{c}\text { a compulsory } \\
\text { education textbook }\end{array}$ & PEP & \multicolumn{2}{|c|}{$\begin{array}{c}\text { PEP deleted the problem and solution } \\
\text { of "taking a taxi". }\end{array}$} \\
\hline 3 & 200511 & $\begin{array}{c}\text { Edition } 2 \\
\text { Impression } 1\end{array}$ & Easy to learn & $\begin{array}{c}\text { Central University } \\
\text { for Nationalities } \\
\text { Press } \\
\end{array}$ & $\begin{array}{c}\text { P20 Example } \\
1\end{array}$ & $\begin{array}{c}10+1.2(\mathrm{X}-5) \leq 17.2 \\
\text { additional description } \\
\text { text }\end{array}$ \\
\hline 4 & 200512 & Impression 4 & $\begin{array}{l}\text { Longmen new } \\
\text { teaching plan }\end{array}$ & Longmen Bookstore & $\begin{array}{l}\text { P22 Leading } \\
\text { Example }\end{array}$ & $\begin{array}{c}10+1.2(X-5) \leq 17.2 \\
\text { and } \\
10+1.2(X-5)>17.2- \\
1.2\end{array}$ \\
\hline 5 & 200710 & $\begin{array}{c}\text { Edition } 2 \\
\text { Impression } 2\end{array}$ & $\begin{array}{c}\text { For special senior } \\
\text { teacher }\end{array}$ & $\begin{array}{c}\text { Inner Mongolia } \\
\text { Children's Publishing } \\
\text { House }\end{array}$ & $\begin{array}{c}\text { P37 Example } \\
4\end{array}$ & $\begin{array}{l}10+1.2(X-5)>16 \\
10+1.2(X-5) \leq 17.2\end{array}$ \\
\hline 6 & 200711 & $\begin{array}{c}\text { Edition } 5 \\
\text { Impression } 1\end{array}$ & $\begin{array}{c}\text { Full explanation of } \\
\text { middle school } \\
\text { textbooks }\end{array}$ & $\begin{array}{l}\text { Shaanxi people's } \\
\text { Education Press }\end{array}$ & $\begin{array}{c}\mathrm{P} 43 \\
\text { Example } 3\end{array}$ & $\begin{array}{l}10+1.2(X-5)>16 \\
10+1.2(X-5) \leq 17.2\end{array}$ \\
\hline 7 & 200801 & $\begin{array}{c}\text { Edition } 3 \\
\text { Impression } 1 \\
\end{array}$ & $\begin{array}{c}\text { Speed training } \\
\text { method }\end{array}$ & $\begin{array}{c}\text { Beijing Education } \\
\text { Press }\end{array}$ & $\begin{array}{c}\text { P19 } \\
\text { Example } 7\end{array}$ & $\begin{array}{c}17.2 \leq 10+1.2(x-4) \\
<18.4\end{array}$ \\
\hline 8 & 200811 & $\begin{array}{c}\text { Edition } 6 \\
\text { Impression } 1\end{array}$ & $\begin{array}{c}\text { Full explanation of } \\
\text { middle school } \\
\text { textbooks }\end{array}$ & $\begin{array}{l}\text { Shaanxi people's } \\
\text { Education Press }\end{array}$ & $\begin{array}{c}\mathrm{P} 48 \\
\text { Example } 5\end{array}$ & $\begin{array}{l}10+1.2(X-5)>16 \\
10+1.2(X-5) \leq 17.2\end{array}$ \\
\hline 9 & 200901 & $\begin{array}{c}\text { Edition } 4 \\
\text { Impression } 1\end{array}$ & $\begin{array}{l}\text { Speed training } \\
\text { method }\end{array}$ & $\begin{array}{c}\text { Beijing Education } \\
\text { Press }\end{array}$ & $\begin{array}{c}\text { P17 } \\
\text { Example } 6\end{array}$ & $\begin{array}{c}17.2 \leq 10+1.2(x-4) \\
<18.4\end{array}$ \\
\hline 10 & There 200901 & & $\begin{array}{l}\text { Speed training } \\
\text { method }\end{array}$ & $\begin{array}{l}\text { Beijing Education } \\
\text { Press }\end{array}$ & \multicolumn{2}{|c|}{$\begin{array}{l}\text { This book deleted the problem and } \\
\text { solution of "taking a taxi". }\end{array}$} \\
\hline 11 & 200910 & Edition 7 & Full explanation of & Shaanxi people's & $\mathrm{P} 42$ & $10+1.2(X-5)>16$ \\
\hline
\end{tabular}




\begin{tabular}{|c|c|c|c|c|c|c|}
\hline & & Impression 1 & $\begin{array}{l}\text { middle school } \\
\text { textbooks }\end{array}$ & Education Press & Example 6 & $10+1.2(X-5) \leq 17.2$ \\
\hline 12 & 201011 & $\begin{array}{c}\text { Edition } 8 \\
\text { Impression } 1\end{array}$ & $\begin{array}{l}\text { Full explanation of } \\
\text { middle school } \\
\text { textbooks }\end{array}$ & $\begin{array}{l}\text { Shaanxi people's } \\
\text { Education Press }\end{array}$ & $\begin{array}{c}\text { P44 } \\
\text { Example } 5\end{array}$ & $\begin{array}{l}10+1.2(X-5)>16 \\
10+1.2(X-5) \leq 17.2\end{array}$ \\
\hline 13 & 201109 & Impression 1 & $\begin{array}{l}\text { Full explanation of } \\
\text { middle school } \\
\text { textbooks }\end{array}$ & $\begin{array}{l}\text { Shaanxi people's } \\
\text { Education Press }\end{array}$ & $\begin{array}{c}\text { P44 } \\
\text { Example } 5\end{array}$ & $\begin{array}{l}10+1.2(X-5)>16 \\
10+1.2(X-5) \leq 17.2\end{array}$ \\
\hline 14 & After 201109 & & $\begin{array}{c}\text { Full explanation of } \\
\text { middle school } \\
\text { textbooks }\end{array}$ & $\begin{array}{l}\text { Shaanxi people's } \\
\text { Education Press }\end{array}$ & \multicolumn{2}{|c|}{$\begin{array}{l}\text { This book deleted the problem and } \\
\text { solution of "taking a taxi". }\end{array}$} \\
\hline 15 & 201110 & 12 & $\begin{array}{l}\text { New classroom for } \\
\text { top students }\end{array}$ & $\begin{array}{c}\text { Liaoning Education } \\
\text { Press } \\
\end{array}$ & $\begin{array}{l}\text { (problem) P17 } \\
\text { (solution) P94 }\end{array}$ & $\begin{array}{c}10< \\
10+1.2(\mathrm{X}-5) \leq 17.2\end{array}$ \\
\hline 16 & 201202 & Impression 3 & $\begin{array}{l}\text { Longmen special } \\
\text { subject }\end{array}$ & Longmen Bookstore & $\begin{array}{c}\text { P139 } \\
\text { Example } 3\end{array}$ & $\begin{array}{l}10+1.2(X-5)>16 \\
10+1.2(X-5) \leq 17.2\end{array}$ \\
\hline 17 & 201210 & Impression 7 & $\begin{array}{c}\text { Focus training in the } \\
\text { whole class }\end{array}$ & $\begin{array}{l}\text { Beijing Education } \\
\text { Press }\end{array}$ & \begin{tabular}{|c|} 
(problem) P54 \\
(solution) \\
P109
\end{tabular} & $\begin{array}{l}10+1.2(\mathrm{X}-5) \leq 17.2 \\
10+1.2(\mathrm{X}-5)>16\end{array}$ \\
\hline 18 & 201211 & $\begin{array}{c}\text { Edition } 1 \\
\text { Impression } 1\end{array}$ & $\begin{array}{l}\text { Homework of new } \\
\text { curriculum reform }\end{array}$ & $\begin{array}{l}\text { Guangxi Normal } \\
\text { University Press }\end{array}$ & \begin{tabular}{|c|} 
(problem) P19 \\
(solution) \\
P150 \\
\end{tabular} & $\begin{array}{c}16< \\
10+1.2(\mathrm{X}-5) \leq 17.2\end{array}$ \\
\hline 19 & 201308 & $\begin{array}{c}\text { Edition } 1 \\
\text { Impression } 5\end{array}$ & $\begin{array}{l}\text { Signature question } \\
\text { library }\end{array}$ & $\begin{array}{l}\text { Shanxi Education } \\
\text { Press }\end{array}$ & $\begin{array}{c}\text { (problem) } \\
\text { P171 } \\
\text { (solution) } \\
\text { P320 } \\
\end{array}$ & $\begin{array}{l}10+1.2(X-5)>16 \\
10+1.2(X-5) \leq 17.2\end{array}$ \\
\hline 20 & 201311 & $\begin{array}{c}\text { Edition } 1 \\
\text { Impression } 1\end{array}$ & Textbook explanation & $\begin{array}{l}\text { Beijing Education } \\
\text { Press }\end{array}$ & $\begin{array}{c}\text { P232 } \\
\text { Example } 4\end{array}$ & $\begin{array}{c}17.2-1.2< \\
10+1.2(X-5) \leq \\
17.2\end{array}$ \\
\hline 21 & 201401 & $\begin{array}{c}\text { Edition } 1 \\
\text { Impression } 6\end{array}$ & $\begin{array}{c}\text { Signature question } \\
\text { library }\end{array}$ & $\begin{array}{c}\text { Shanxi Education } \\
\text { Press }\end{array}$ & $\begin{array}{c}\text { (problem) } \\
\text { P171 } \\
\text { (solution) } \\
\text { P320 } \\
\end{array}$ & $\begin{array}{c}10+1.2(X-5)>16 \\
10+1.2(X-5) \leq 17.2\end{array}$ \\
\hline 22 & 201512 & $\begin{array}{c}\text { Edition } 1 \\
\text { Impression } 2\end{array}$ & $\begin{array}{c}\text { Textbook } \\
\text { interpretation }\end{array}$ & PEP & $\begin{array}{c}\text { P138 } \\
\text { Example } 4\end{array}$ & $\begin{array}{c}17.2-1.2< \\
10+1.2(X-5) \leq \\
17.2\end{array}$ \\
\hline 23 & 201609 & $\begin{array}{c}\text { Edition } 1 \\
\text { Impression } 3\end{array}$ & $\begin{array}{c}\text { Textbook } \\
\text { interpretation }\end{array}$ & PEP & $\begin{array}{c}\text { P138 } \\
\text { Example } 4\end{array}$ & $\begin{array}{c}17.2-1.2< \\
10+1.2(X-5) \leq \\
17.2\end{array}$ \\
\hline 24 & 20 & & $\begin{array}{c}\text { Textbook } \\
\text { interpretation }\end{array}$ & PEP & $\begin{array}{r}\text { PEP deleted the } \\
\text { of "ta }\end{array}$ & $\begin{array}{l}\text { oroblem and solution } \\
\text { ing a taxi". }\end{array}$ \\
\hline
\end{tabular}

\subsection{Other mistakes similar to the mistake in "taking a taxi"}

In 2001, the textbook for grade one of senior high school published by PEP made a mistake in solving the problem of "demolishing and building houses"; In January 2001, the textbook for grade one of junior high school published by PEP made a mistake in solving the problem of "sharing apples"; On August 27, 2001, Sanxia Evening News called for the correction of the mistake in "sharing apples". Then in November 2001, PEP made a mistake again when correcting the mistake in "sharing apples". According to the equation listed in the textbook, students could only have an answer of six and a half children. On November 11, 2003, China Central Television supervised the mistake.
Since such mistakes were frequent at that time, the State Administration of Press and Publication, a department responsible for book quality supervision in China, once issued a notice on the special inspection of the quality of textbooks and supplementary books in 2004 . However, the fact that the mistake in "taking a taxi" is still frequent for a long time shows that this special inspection has not yet received its desired effect.

The famous American mathematician Halmos said that the real parts of mathematics were problem and its solution[2]. Therefore, we should find out the root of frequent mistakes like that in "taking a taxi" and take effective measures to solve them thoroughly. 


\subsection{Solving word problems with equations or equation sets is an unsolved issue in China}

As pointed out in Teaching Methods in Middle School Mathematics Textbooks, a textbook for higher normal colleges published by East China Normal University in 2016, there are still many major issues for people to study and to fill in gaps. Teaching Methods in Middle School Mathematics Textbooks published by East China Normal University in 2002 also holds that solving word problems with equations or equation sets is an important topic.

Some influential textbooks in China have explored this topic.

For example, on page 245 of the second volume of Teaching Methods in Middle School Mathematics Textbooks published by East China Normal University in 2002, the general steps for solving word problems with equations or equation sets are summarized as follows:

(1) Suppose: use the letter $\mathrm{x}$ or $\mathrm{y}, \ldots$ to represent the unknown number in the problem.

(2) Table: use the formula containing the unknown number to represent the relevant algebraic formula in the problem.

(3) Column: list an equation according to the equality relationship between the known number and the unknown number in the problem.

Take, for another example, the first volume of the textbook for grade seven published by PEP in 2020. On page 101, the basic process of solving problems with linear equations in one unknown is summarized as figure 1:

\begin{tabular}{|c|c|c|}
\hline \multirow{2}{*}{ Practical problem } & Set up the unknowns & \multirow{2}{*}{$\begin{array}{l}\text { linear equations in one } \\
\text { unknown }\end{array}$} \\
\hline & list equations & \\
\hline $\begin{array}{l}1 \\
1 \\
1 \\
1 \\
1 \\
1\end{array}$ & & 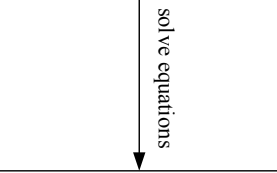 \\
\hline $\begin{array}{l}\text { Solution to the practical } \\
\text { problem }\end{array}$ & examine & $\begin{array}{l}\text { the solution of a linear } \\
\text { equation in one unknown }\end{array}$ \\
\hline
\end{tabular}

Figure 1. The basic process of solving problems with linear equations in one unknown

The above-mentioned different expressions not only show the internal exploration in the field, but also show that there isn't an uncontested conclusion in the field yet. Therefore, it is necessary to develop a more comprehensive and rigorous method to solve word problems with equations or equation sets.

\section{THE SOLUTION TO THE PROBLEM OF "FINDING OUT ALL THE EQUALITY RELATIONSHIPS"}

Based on the essential definition of equation, that is, an equation with unknown number is called an equation, and the logic structure in mathematical problem solving, it is found that when solving word problems with equations or equation sets, all the equivalent relationships in the problem are the sufficient and necessary condition for solving the problem correctly, and by finding out all the equivalent relationships, a solution to the topic of solving word problems with equations or equation sets can be achieved.

\subsection{All the equality relationships are the sufficient condition for solving word problems with equations or equation sets}

Take, for example, the problem of "the number of students" on page 79 of the first volume of the textbook for grade seven published by PEP in 2020 .

Problem 2: Girls account for 52\% of all students in a school, which is 80 more than boys. How many students are there in this school?

The solution to the problem of "the number of students" in the textbook is as follows:

According to "girls account for $52 \%$ of all students", "the number of girls $=52 \% \times$ the number of all students" (1) can be listed.

"The number of girls" and "the number of all students" are unknown numbers expressed in the form of words, and actually they are. Therefore, according to the definition of equation, that is, an equation with unknown number is called an equation, it can be seen that (1) is not only an equality relationship, but also an equation. If the equality relationship is found out, an equation can be listed.

(1) is an equation with two unknown numbers. This alone cannot solve the problem. It is necessary to find out other equality relationships, that is to say, to list other equations. According to "girls ... 80 more than boys", "the number of girls - the number of boys $=80$ " (2) can be listed.

Although two equations have been listed, the number of unknowns has increased to three. Therefore, it is still necessary to find out other equality relationships.

With a little analysis, "the number of girls + the number of boys = the number of all students" (3) can be listed.

So far, three equations are listed, among which the number of unknowns is also three.

The combination of (1), (2) and (3) forms an equation set containing three unknowns and three equations.

$$
\left\{\begin{array}{l}
\text { "the number of girls }=52 \% \times \text { the number of all } \\
\text { students" }(1) \\
\text { "the number of girls - the number of boys }=80 "(2) \\
\text { "the number of girls }+ \text { the number of boys }=\text { the } \\
\text { number of all students" (3) }
\end{array}\right.
$$

This is actually a system of linear equations with three unknowns. Based on deformation calculation (due to space limitations, the process is omitted here), the ranks of the coefficient matrix and the augmented matrix are both equal to 3 in this system of linear equations, that is, $\mathrm{R}(\mathrm{A})=\mathrm{R}(\mathrm{A}, \mathrm{b})=3$. Therefore, according to the theorem that the sufficient and necessary condition for $A x=b$, an $\mathrm{n}$-variable linear equations, to have a unique solution is $R(A)=R(A, b)=n "$, it can be seen that the above equation set has a unique solution. 
Solve this equation set again. From $(2)+(3)-2 \times(1)$, we can have:

"the number of girls - the number of boys + the number of girls + the number of boys $-2 \times$ the number of girls $=80+$ the number of all students $-2 \times 52 \% \times$ the number of all students"

"0 $0=80-4 \% \times$ the number of all students"

Namely, "the number of all students $=2,000$ "

So far, it can be seen that when the number of equality relationships is equal to the number of unknowns, all the equality relationships required to solve the problem have been found out. Then, the solution of the word problem surely can be obtained. Therefore, all the equality relationships are the sufficient condition for solving word problems with equations or equation sets.

As to the above equation set, its writing is very cumbersome, while a simply written equation set can be obtained by replacing the number of all students, the number of girls, and the number of boys with simple symbols such as $\mathrm{x}, \mathrm{y}$, and $\mathrm{z}$.

$\left\{\begin{array}{l}y=52 \% x \\ y-z=80 \\ y+z=x\end{array}\right.$

From this, the method of solving word problems with systems of multivariate equations can be concluded as follows:

1. To find out all the equality relationships. The standard of finding out the whole is that the number of equality relationships is equal to the number of unknowns. In essence, it means to list the whole equations;

2. To use letters, such as $\mathrm{x}, \mathrm{y}$, etc. to replace all the unknowns expressed in words, so as to obtain a simply written equation set;

3. To solve the equation set.

In this method, all the unknowns expressed in words are replaced by letters, and then an equation set is listed. The author defines it as the method of solving word problems with systems of multivariate equations.

In solving the problem of "the number of students" with systems of multivariate equations, the three equality relationships are the basis of listing equations. That is to say, this kind of solution cannot be separated all the equality relationships. As to the above method of finding out all the equality relationships, the author refers to it as "the method of finding the whole" for short. Accordingly, in solving word problems with inequalities, the author advocates the method of finding out all the equality relationships and inequality relationships and refers to it as "the method of finding the whole in a broad sense" for short.

\subsection{All the equality relationships are the necessary condition for solving word problems with equations or equation sets}

Through the analysis of the solution of the problem of "the number of students" in the textbook published by PEP, this paper explains that all the equality relationships are the necessary condition for solving word problems with equations or equation sets.

The solution in the textbook published by PEP: Suppose the number of students in this school is $\mathrm{x}$. Then the number of girls is $0.52 \mathrm{x}$, and the number of boys is $(1-0.52) \mathrm{x}$.

The equation is " $0.52 \mathrm{x}-(1-0.52) \mathrm{x}=80$ ".

On the surface, the above solution does not use any equality relationship. But in fact, the number of girls, 0.52 $\mathrm{x}$, is listed based on the equality relationship (1) after the number of students is set as $\mathrm{x}$; the number of boys, $(1-0.52) \mathrm{x}$, is listed based on the previous results and the equality relationship (3); the final equation, $0.52 \mathrm{x}-(1-0.52)$ $\mathrm{x}=80$, is listed according to the equality relationship (2). Therefore, the solution of the problem of "the number of students" in the textbook cannot do without all the equality relationships.

Therefore, both the method of solving the problem of "the number of students" with a system of multivariate equations and the method of solving it with an equation in one unknown, in essence, cannot be divorced from all the equality relationships.

If other methods are adopted to solve the problem of "the number of students", it can be found that those methods are still inseparable from all the equality relationships. That is to say, all the equality relationships are the necessary condition for solving word problems with equations or equation sets. Therefore, it is necessary to find out all the equality relationships when solving word problems with equations or equation sets. Unfortunately, the current textbooks like the one printed by PEP have not found all the equality relationships.

Through the analysis of the solution in the textbook printed by PEP, the method of solving word problems with equations in one unknown can also be concluded as follows:

1. To find out all the equality relationships. The standard of finding out the whole is that the number of equality relationships is equal to the number of unknowns;

2. To appropriately choose an equality relationship as the basis of an equation. And other equality relationships can be used as the basis of algebraic expressions;

3. To appropriately use a letter, like $x$, to replace an unknown number expressed in words;

4. To list algebraic expressions based on the equality relationships;

5. To list equations based on the equality relationships;

6 . To solve the equation.

Then by summarizing the method of solving word problems with systems of multivariate equations or with equations in one unknown, the laws can be found:

In solving word problems with equations or equation sets, effective solutions can be achieved, as long as all the equality relationships are found out, and then several of the equality relationships are adopted as the basis of equations, with the remaining equality relationships as the basis of algebraic expressions. This conclusion is the author's solution to the topic of solving word problems with equations or equation sets. 


\section{THE APPLICATION OF THE METHOD OF FINDING OUT ALL THE EQUALITY RELATIONSHIPS AND INEQUALITY RELATIONSHIPS IN SOLVING THE PROBLEM OF "TAKING A TAXI"}

\subsection{Find out all the equality relationships and inequality relationships first}

Firstly, according to "pay 10 yuan for a driving distance within $5 \mathrm{~km}$ ", "the paid fare $=10(0<$ the driving distance $<5 \mathrm{~km}) "$ (1) can be listed.

Then it is natural to ask: How should one pay when the driving distance is equal to or greater than $5 \mathrm{~km}$ ?

Secondly, according to the meaning of the problem and combined with the experience of riding a taxi, it can be found from the driving process of the taxi.

When the driving distance is equal to $5,5.1,5.2, \ldots 5.9$, that is, if it is equal to 5 , or greater than 5 but less than 6 , the paid fare is $(10+1.2)$ yuan. Therefore, when the integer part of the driving distance is equal to 5 , the paid fare will increase by 1.2 yuan (1).

It can be seen from the above that when the integer part of the driving distance is equal to 6 , the paid fare increases by two 1.2 yuan $(2)$

By synthesizing (1), (2), etc., "the paid fare $=10+1.2 \times$ (the integer part of the driving distance - 4) (the driving distance is greater than or equal to $5 \mathrm{~km}$ )" (2) can be listed. The problem requires the driving distance, which has not yet appeared in the equality relationships that have been found, so it is necessary to find the relationship between the driving distance and quantities in equality relationships.

Thirdly, it can be found from the driving process of the taxi by means of the number axis.

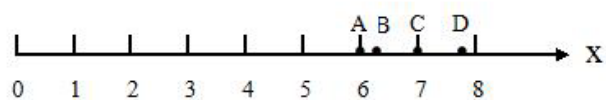

Figure 2. Number axis

By observing the number axis, we can see that when the taxi reaches $\mathrm{A}$, the driving distance $=6$, and the integer part of the driving distance $=6$, so, driving distance $=$ the integer part of the travel mileage (3).

When the taxi goes to $\mathrm{B}$, the driving distance $=6.2$. The two adjacent integers, 6 and 7, respectively are the integer part of the driving distance and the integer part of the driving distance +1 , so the integer part of the driving distance $<$ the driving distance $<$ the integer part of the driving distance +1 (4).

It can also be seen from the above that when the taxi arrives at $\mathrm{C}$, the integer part of the driving distance $=$ the driving distance $<$ the integer part of the driving distance + $1(5)$.

Therefore, by synthesizing (3), (4), (5), etc., the following inequality relationship can be obtained:

The integer part of the driving distance $\leq$ the driving distance $<$ the integer part of the driving distance +1 (3)

So far, the following equality and inequality relationships have been found:

The paid fair $=\{10(0<$ the driving distance $<5 \mathrm{~km})$ (1)

$\{10+1.2 \times$ (the integer part of the driving distance - 4) (the driving distance is greater than or equal to $5 \mathrm{~km})$ (2)

The integer part of the driving distance $\leq$ the driving distance $<$ the integer part of the driving distance +1 (3)

\subsection{Solve the problem of "taking a taxi" again}

Suppose the driving distance is $\mathrm{x} \mathrm{km}$. Then the integer part of the driving distance is [x]. When the paid fare is 17.2 yuan, the driving distance has exceeded $5 \mathrm{~km}$. Therefore, substitute the paid fare, 17.2 yuan, and the integer part of the driving distance, $[\mathrm{x}]$, into (2).

" $17.2=10+1.2 \times([\mathrm{x}]-4) "$ can be listed.

So, $[\mathrm{x}]=10$.

Then substitute it and the driving distance, $x$, into (3).

"10 $\leq \mathrm{x}<10+1$ " can be obtained.

So, $10 \leq \mathrm{x}<11$, which means that the distance from place A to place $B$ is equal to $10 \mathrm{~km}$ or greater than $10 \mathrm{~km}$ and less than $11 \mathrm{~km}$.

\subsection{The criterion for finding out all the equality relationships and inequality relationships}

When a detailed, complete, and correct solution to a problem can be obtained, the equality relationships and inequality relationships found are all the equality relationships and inequality relationships. This is similar to the criterion for whether the proof process of geometry problems is complete: when the proof process is detailed, clear, flawless, and correct, the process presented is a complete proof process.

So far, it can be seen that the way to avoid the mistake in "taking a taxi" is to grasp the method of finding out all the equality relationships. With this necessary foundation, in solving the problem of "taking a taxi", all the equality relationships and inequality relationships can be found out, so as to obtain the correct solution.

\section{CONCLUSION}

Aiming at the limitations of the current method of solving word problems with equations, this paper puts forward "the method of finding the whole", which is to find all the equal 
and unequal relations in the complete applied problems that meet both sufficient and necessary conditions. Compared with the currently used literal translation method and backward inference method, the "find the whole method" is more rigorous in solving problems. Compared to the table method, "find the whole method" is more direct and convenient. Therefore, "find the whole method" is recommended to use as the optimization method for solving word problems with equations for middle school students.

\section{REFERENCES}

[1] Z.W. Zhao. The first volume of teaching methods in middle school mathematics textbooks, 2nd ed. East

China Normal University Press, Shanghai, China, 2016, Introduction.

[2] Z.W. Zhao. The second volume of teaching methods in middle school mathematics textbook (Revised edition). East China Normal University Press. Shanghai, China, 2002, pp.244-245.

[3] X. L. Lv. The first volume of algebra for three-year junior high school of nine-year compulsory education. People's Education Press, Beijing, China, 1994, pp.26.

[4] Department of Mathematics of Tongji University. Engineering Mathematics. Linear Algebra, 5th ed. Higher Education Press, Beijing, China, 2007, pp. 71.
[5] J.C.Ying. "Several basic problems to be solved in the teaching of solving word problems with equations." Mathematics Education in China (Junior High School Edition). vol. 3, pp. 7-10, 2020.

[6] H. D. Li. Compulsory education textbook: the first volume of mathematics for grade seven (First Edition). People's Education Press. Beijing, China,2020, pp.79. pp.101

[7] C.Q. Zhou. "Common methods for solving word problems with linear equations in one unknown". Learning in Chinese, Mathematics and English (Junior High School Edition). vol. 10, pp. 27-28, 2019.

[8] S.C.Ge. "Several common mistakes in solving word problems with equations." Learning in Chinese, Mathematics and English (Junior High School Edition). vol. 6 , pp. 31-32,2019.

[9] E. Q. Dai. Solving word problems with equations. Hubei Education Publishing House, Hubei, china, 2000, pp. 37-51.

[10] E. Q. Dai. Methods of solving word problems and imperfect understanding of textbooks. Taiwan Mathematics Teachers (Electronic) Journal of Taiwan Mathematics Education Association. vol.2, pp. 31-37,2005. 